\title{
Ritual and the cosmos: astronomy and myth in the Athenian Acropolis
}

\author{
Efrosyni Boutsikas ${ }^{1}$ and Robert Hannah ${ }^{2}$ \\ ${ }^{1}$ Department of Classical \& Archaeological Studies, University of Kent, \\ Canterbury CT2 7NF, United Kingdom \\ email: E.Boutsikas@kent.ac.uk \\ ${ }^{2}$ Department of Classics, University of Otago, P.O. Box 56, Dunedin, New Zealand \\ email: robert.hannah@otago.ac.nz
}

\begin{abstract}
The paper deals with the cult of the daughters of the mythical king of Athens, Erechtheus, who lived on the Acropolis. This myth establishes the deceased daughters as goddesses who are owed cult by the Athenians. It further equates them with the Hyades, a prominent star cluster in the constellation of Taurus, which they form after their deaths. We examine here the possibility that this myth not only narrates the placement of the girls after their death in the sky in the form of the Hyades, but also may have bound the constellation to certain festivals held on the Acropolis, which through their aetiological myths were connected to the daughters of Erechtheus and in which the participation of young girls (Arrhēphoroi) was important. To explicate this cult, we explore its context on the Acropolis as fully as possible, through the visual arts, the literary myth, the festival calendar, and the natural landscape and night-sky, so as to determine whether the movement of the constellation of the Hyades was indeed visible from the Acropolis during the time when the young maiden cult rites were performed on the hill.
\end{abstract}

Keywords. Athens, Acropolis, Arrhēphoroi, Hyades

According to a Greek tragedy, Erechtheus, written by Euripides in the 5th century BC, the mythical king of Athens, Erechtheus, sent ambassadors to the Delphic oracle to ask what he needed to do to ensure victory in the war against nearby Eleusis. The oracle responded that he had to sacrifice one of his three daughters. The youngest daughter of the king was chosen for the sacrifice. Her two sisters, however, had sworn that they should all die together, and committed suicide by throwing themselves off the Acropolis, where the king and his family lived. Euripides goes on to say that upon the death of the maidens, Athena appears and proclaims that the souls of Erechtheus' three daughters "have not gone to Hades". Instead, she has "caused their spirit to dwell in the upper reaches of the sky and [she] shall make a famous name throughout Hellas for men to call them the Hyakinthian goddesses" (Erechtheus, fr. 370: 71-74). An ancient commentator identifies these with the star cluster of the Hyades (scholiast on Aratos, Phaenomena 172). This proclamation of the placing of the girls in the night-sky as the constellation of the Hyades is followed by another proclamation of Athena that the girls are from now on to be considered goddesses and that the Athenians should offer them annual sacrifices and choral dances performed by young girls.

Apart from the myth narrating the death of the daughters of Erechtheus, another Acropolis myth also talks of young maidens killing themselves by jumping off the Acropolis hills (Apollodoros, Library 3.14.2; Philochoros, FGrH 328 F 105). These were the three daughters of another mythical Athenian king, Kekrops: Herse, Aglauros and Pandrosos. The reason for the death of these maidens was their disobeying of Athena's orders not to open the box containing the newborn Erichthonios. The girls threw themselves 
from the Acropolis in a frenzy of madness sent upon them by Athena as punishment. King Kekrops and his family would have dwelt on the Acropolis.

The major religious festival celebrated on the Athenian Acropolis that is associated with young girls is called the Arrhēphoria, a name that in antiquity was interpreted as signifying either the carrying of 'mysterious things' (arrhetta) or, owing to a variant spelling Errhephoria, a specific association with the daughters of Kekrops through Herse, whose name was alternatively spelled Erse. The rite was a nocturnal one and took place in the north and north-eastern part of the Acropolis. The four girls who served the cult were aged between 7 and 11, and chosen annually from the noble families of Athens. Called Arrhêphoroi, they dwelt on the Acropolis and were associated particularly with the production of Athena's peplos. Two of them, the sources tell us, were tasked with overseeing the weaving of the peplos, while the other two, it seems, were responsible for carrying the sacred vessels of Athena (Suda and Etymologicum Magnum, s.v. Arrhēphoroi; Pausanias 1.27.3). The Arrhêphoroi, along with other young girls, played a significant role in at least three Acropolis cults: the Kallynteria, the Plynteria, and the Arrhepphoria.

The Kallynteria, Plynteria, and Arrhēphoria were all nocturnal rites and took place in the north and north-eastern part of the Acropolis (Fig. 1). The Kallynteria involved the cleansing of the shrine of Athena Polias within the Erechtheion sanctuary, and the re-lighting of the eternal flame of the goddess. The festival was associated with the death of Aglauros, the daughter of Kekrops, who was the first to adorn the gods (Photios, s.v. Kallynteria). During the Plynteria, the cult statue of the goddess was stripped and carried in a night procession to the seashore. The Arrhepphoria was something like an initiation rite for a few select young Athenian girls aged around 7 to 11, commemorating the three daughters of Erechtheus. On the night before the day celebrating the festival, the priestess of Athena gave the Arrhephoroi baskets, the contents of which were not known to them and which they were asked to take to the sanctuary of Aphrodite through a secret passage, descending from the north slopes. The girls were to leave the baskets they were carrying, pick up some new ones from the sanctuary of Aphrodite (again with unknown contents) and bring them back to the Acropolis (Pausanias 1.27.3).

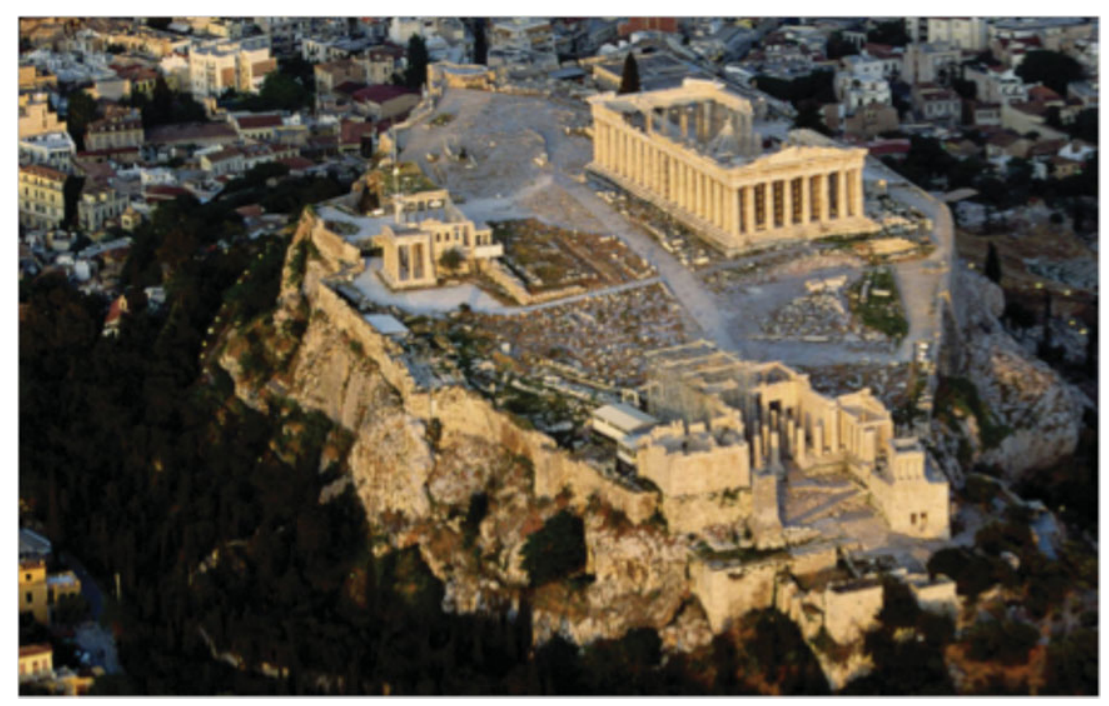

Figure 1. The Athenian Acropolis, seen from the western entrance. The Parthenon is at the top right, on the southern side of the hilltop, and opposite it on the northern side is the Erectheion. The Arrhēphoro $i$ would descend from near here down the north slope. 


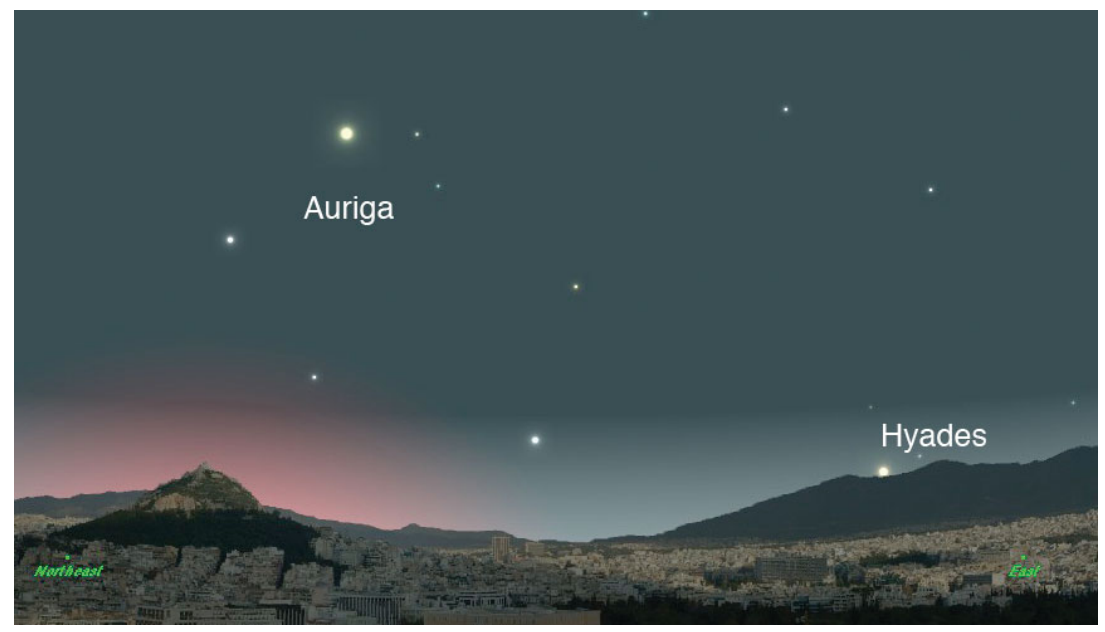

Figure 2. Heliacal rising of the Hyades over the 'Horns' of Mt Hymettos, as seen from the east end of the Parthenon in Athens, 600 BC. Auriga is already risen and sits over Mt Lykabettos to the north-east. (Voyager 4.5, with Athenian horizon incorporated by R. Hannah)

It was noted above how the daughters of Erechtheus were transformed after death into the Hyades. Let us now consider whether there is any relationship between the rites on the Acropolis that involve young girls and the phases of the Hyades. The heliacal rising of the Hyades would have been visible from the Athenian horizon between 6 and 8 June in the years between 700 and 300 BC. The invisibility period of the Hyades in Greece started in the same period on 9 April and ended on 5 June. So during its helical rising, the star cluster would become visible again for the first time, after an invisibility period of approximately a month. The constellation became visible for the first time approximately one hour before sunrise for a few minutes only.

The rising Hyades are located on the eastern horizon. This part is visible on the Athenian Acropolis if the observer is standing in front of or near the entrance of the Parthenon, the Great Altar and the east porch of the Erechtheion (Fig. 2). This eastern horizon visible from the east part of the Acropolis is not particularly high. Its outline is formed by Mt Hymettos across the east and with Mt Lykabettos rising sharply at a much closer distance in the east-northeast.

Towards the end of the night at the time of the Arrhēphoria, the young Arrhepphoroi would have climbed back to the top of the Acropolis. When the nocturnal cult rite would have been completed, the Hyades would be seen climbing up the eastern section of the horizon. It is our assertion that this astronomical phenomenon would have been expected because of the timing of the rite.

Table 1 shows a correlation between the rites associated with the young girls (the Arrhephoroi, and the daughters of Kekrops and Erechtheus) and the movement of the Hyades, believed to have been the personification of the mythical young girls. The Kallynteria, which marked the commencement of three consecutive rites timed within three weeks of one another, were set at the period of or very close to the most astronomically significant phase of the constellation of the Hyades and Auriga. Interestingly, Auriga was for the Greeks the stellar representation of Erechtheus/Erichthonios. The rising constellation is located in the northeast part of the night sky. Between 700 and 300 BC, Auriga's heliacal rising occurred between 3 and 5 June, neatly coinciding with that of the Hyades around 6-8 June. Auriga's invisibility period started on 23 May, only two weeks earlier than that of the Hyades. 
Table 1. Calendrical correlation between festivals involving young girls and the movements of the Hyades and Auriga. Timings are for $600 \mathrm{BC}$.

\begin{tabular}{|c|c|c|c|c|}
\hline Gregorian months & Attic months & Festivals & HYADES & Auriga \\
\hline July-August & Hekatombaion & Panathenaia & & \\
\hline August-September & Metageitnion & & & \\
\hline September-October & Boedromion & Genesia -5 th & & \\
\hline October-November & Pyanepsion & $\begin{array}{l}\text { Weaving of peplos } \\
\text { starts }\end{array}$ & $\begin{array}{l}\text { Acronychal rising } \\
(15-17 \text { Oct }) ; \\
\text { Cosmical setting } \\
(5-7 \text { Nov })\end{array}$ & $\begin{array}{l}\text { Acronychal rising } \\
\text { (18-20 October) }\end{array}$ \\
\hline November-December & Maimakterion & & & $\begin{array}{l}\text { Cosmical setting } \\
(22-24 \text { Nov })\end{array}$ \\
\hline December-January & Poseideon & & & \\
\hline January-February & Gamelion & & & \\
\hline February-March & Anthesterion & & & \\
\hline March-April & Elaphebolion & & $\begin{array}{l}\text { Heliacal setting } \\
(6-8 \text { April })\end{array}$ & $\begin{array}{l}\text { Heliacal setting } \\
(27-29 \text { April })\end{array}$ \\
\hline April-May & Mounychion & & $\begin{array}{l}\text { Invisibility period } \\
(9 \text { April-...) }\end{array}$ & \\
\hline May-June & Thargelion & $\begin{array}{l}\text { Kallynteria }(22 \mathrm{nd}) \\
\text { Plynteria }(25 \mathrm{th})\end{array}$ & $\begin{array}{l}\text { Invisibility period } \\
(\ldots-5 \text { June }) ; \\
\text { Heliacal rising } \\
\text { (6-8 June) }\end{array}$ & $\begin{array}{l}\text { Invisibility period } \\
\text { (23 May-2 June); } \\
\text { Heliacal rising } \\
\text { ( } 3-5 \text { June) }\end{array}$ \\
\hline June-July & Skirophorion & Arrhēphoria (3rd?) & & \\
\hline
\end{tabular}

A similar astronomical association occurs at the time when the weaving of Athena's peplos would have commenced, in Pyanepsion (October-November). This is the time when the acronychal rising (constellation seen to rise at dusk just after sunset) (1517 October) and the cosmical setting (constellation seen to set just before dawn) (5-7 November) of the Hyades would have occurred.

Greek calendars were luni-solar. The months started with the first sighting of the new moon, an observation that is susceptible to weather conditions. Therefore, stellar observations would have ensured that festivals were celebrated around the correct time every year.

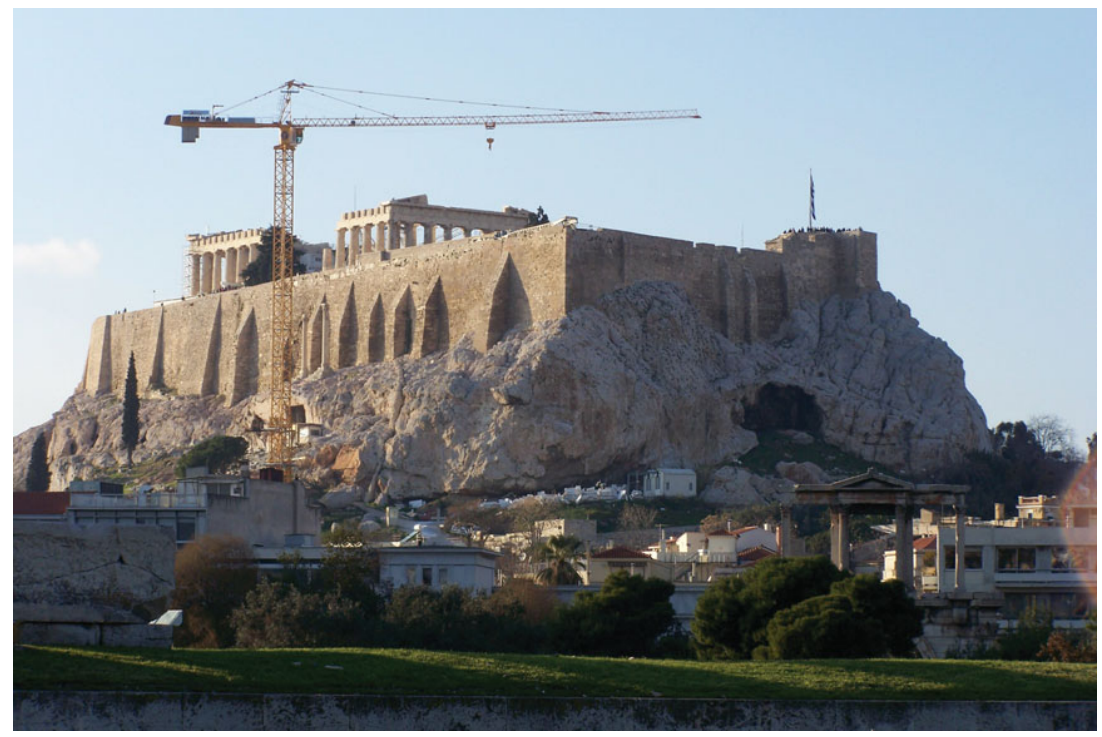

Figure 3. South-east corner of the Athenian Acropolis. The Cave of Aglauros dominates the lower east slope to the right. (Photo R. Hannah) 
At the bottom of the east slope of the Acropolis rocks, a small cave-sanctuary has been discovered, dedicated to Aglauros, one of Kekrops' daughters, and probably commemorating her and her sisters' deaths (Fig. 3). It is possible that the location of this sanctuary was not accidental, but instead was believed to have marked the spot where the young girls died after jumping from the east part of the Acropolis.

The festival held in the sanctuary in honour of Aglauros and her two sisters took place in the same month as the Arrhepphoria and included a night-long cult rite (pannychis). Even though the cave of Aglauros is located at a considerably lower altitude, at the foot of the Acropolis hill, at the time of the festival of Aglauros the rising Hyades would still have been seen in the east, over the horizon that the cave faces. We have then a spatiotemporal association that links the mythological narratives - used as foundation myths (aitia) of cults on the Acropolis - with the optimal location from which the relevant astronomical observations could be visible during the rites; a case where time and space entwine. In addition to the spatial association, the rites were timed on the occasion of the most astronomically significant phases of the same constellations. This cosmic association-between, on the one hand, the myth of the death of the young maidens, the timing of religious rites in which these girls were commemorated, and the location where the rites would have taken place and, on the other hand, the astronomical observationswould have come together once a year, at the precise moment in time when the cosmos would transition from night to day.

This transition between night and day is also marked on the Parthenon's east pediment and north metopes, which depict events that were supposed to have taken place at dawn. The east pediment (Fig. 4) depicts the Birth of Athena. In one corner the sun-god Helios and his chariot are rising, while at other end Selene the Moon, in her chariot, is descending. The base of the pediment functions as a virtual horizon. A very similar depiction is present in the north metopes, which depict episodes from the Trojan War.

The Parthenon's east frieze, which is the part facing towards the eastern horizon from where the Hyades are visible, depicts a larger number of maidens than any other sculptural decoration on the Acropolis. Here, over 30 maidens are depicted, while the place of prominence in the frieze is occupied by the depiction of three girls and a woman (Fig. 5). These girls may have been the daughters of Erechtheus, or the scene may be depicting the young Arrhephoroi. The narration of the sculptural decoration of the Parthenon is therefore linked by projecting one's field of view from the east frieze to the east horizon, where the Hyades would have been visible.

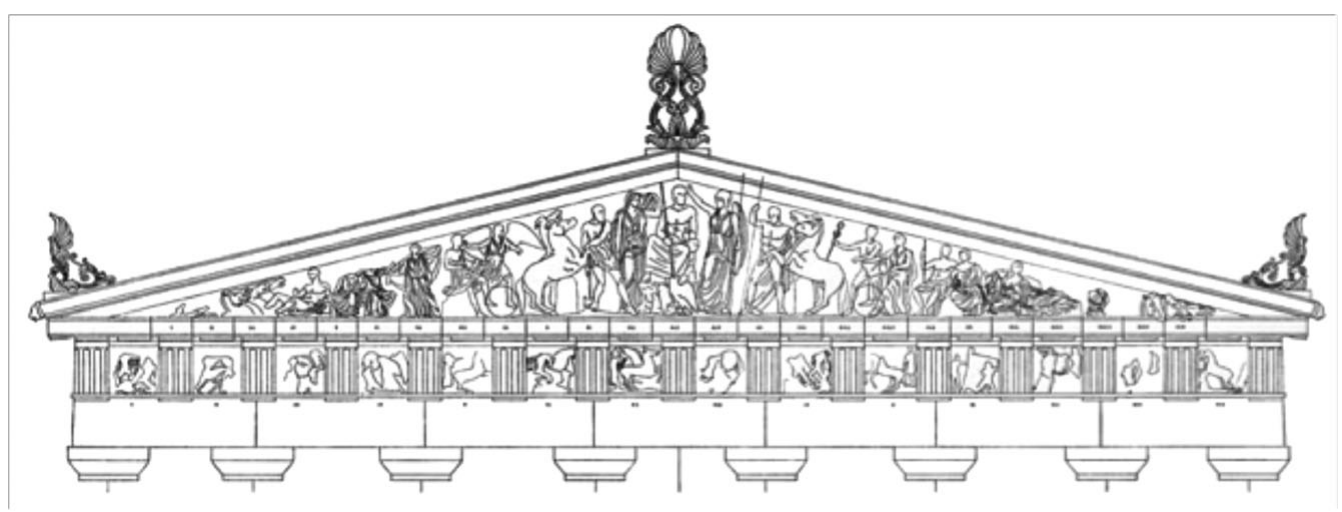

Figure 4. East pediment of the Parthenon, 438-432 BC. (After Hurwit 1999) 


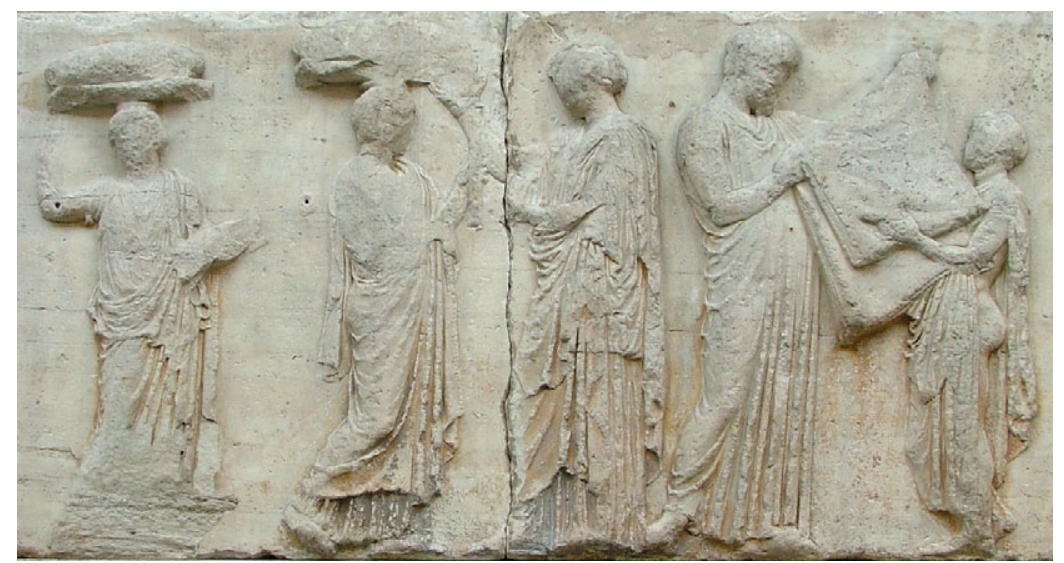

Figure 5. Central scene of the East frieze of the Parthenon, 442-438 BC, British Museum, London. (Photo R. Hannah)

In ancient Greek culture, the observation of heliacal risings was a practice that dates to at least Homeric times, as this passage from the Iliad demonstrates in its decsription of the appearance of Sirius in late summer:

"Thus Achilles swiftly plied his feet and knees. Aged Priam was first to see him with his eyes, shining as he sped over the plain, like the star which comes in late summer, and his bright rays appear among the many stars in the darkness of night, the star which they call by name the Dog of Orion." (Homer, Iliad 22.24-30, transl. R. Hannah)

The practice was so widespread that by the 7th century BC we have an entire farmer's almanac by Hesiod called Works and Days, which lists agricultural activities against the movement of a handful of stars and constellations, such as the Pleiades:

"When the Pleiades born of Atlas rise, begin the reaping; the ploughing, when they set." (Hesiod, Works and Days 383, transl. E. Boutsikas)

In the religious context, literary sources and archaeological material attest that astronomy, and more specifically the rising of stars and constellations, played a significant role in Greek religion and cult practice. The nocturnal character of Greek religious festivals performed in an open space, with little artificial light, suggests the importance of the celestial dome, encircling these performances, integrating the sky in the cult experience. In addition, the fundamental importance of astronomy and time measurement to coordinate religious festivals is supported by the discovery of a sundial in the temple of Apollo in Klaros in western Turkey and of the Hibeh papyrus from Hellenistic Greek Egypt, which recorded astronomical movements plotted against religious festivals.

Putting the archaeological evidence to one side, the written sources also indicate that watching the sky for astronomical observations and meteorological phenomena as signs of divine intervention, or the arrival of the correct time for rituals, is common in ancient Greece, as we see in these passages from the playwrights Aristophanes and Euripides in the late 5th century BC:

"Awake, for it has come shaking flaming torches in its hands, Iacchos, Oh Iacchos, the light-bearing star of our nocturnal rite." (Aristophanes, Frogs 342-3, transl. R. Hannah)

"I see this tomb of my thunder-stricken mother near the palace, and the ruins of her house, smouldering with the still living flame of Zeus' fire..." (Euripides, Bacchae 6-10, transl. R. Hannah) 
The earliest and most striking example of an astronomical observation connected to religious practice is the case of the inhabitants of Keos, who watched the sky for the arrival of Sirius and offered sacrifices to the star. The rite seems to date to at least the fourth century BC (Burkert 1983: 109-111; Davidson 2007: 207):

"But when from heaven Sirius burned the Minoan islands, and for a long time there was no remedy for the inhabitants, then by the command of the Far-Shooter they summoned a protector from the plague. And at his father's command he left Phthia and settled in Keos, gathering together the Parrhasian people who are of the race of Lykaon, and he made a great altar to Zeus Ikmaios, and duly offered sacrifices on the mountains to that star Sirius, and to Zeus son of Kronos himself. And because of this the Etesian winds from Zeus cool the land for forty days, and in Keos even now priests offer sacrifices before the rising of the Dog-star." (Apollonios, Argonautica 2.516-27, transl. R. Hannah)

References to astronomical observations and cosmological beliefs within a religious context are also found in Greek mythology, pottery, sculpture figurines, etc.

We conclude that an astronomical relationship existed between the cults of young girls on the Acropolis and the movement of the constellation of the Hyades. In this paper we have argued that the architectural structures, as well as the cult rites, with their timing and foundation myths, were all tightly interwoven in expressing a religious and cosmological narrative and context.

\section{References}

Ancient sources:

Apollodorus, The Library, 2 vols, transl. J. G. Frazer, Harvard University Press, Cambridge MA, 1921.

Apollonius Rhodius, Argonautica, transl. W. H. Race, Harvard University Press, Cambridge MA, 2009.

Aristophanes, Frogs, in Aristophanes, vol. IV, transl. J. Henderson, Harvard University Press, Cambridge MA, 2002.

Euripides, Bacchae, in Euripides, vol. 6, transl. D. Kovacs, Harvard University Press, Cambridge MA, 2003.

Euripides, Erechtheus, in Euripides, vol. 7, transl. C. Collard \& M. Cropp, Harvard University Press, Cambridge MA, 2008.

Hesiod, Works and Days, in Hesiod, vol. 1, transl. G. W. Most, Harvard University Press, Cambridge MA, 2007.

Homer, Iliad, 2 vols, transl. A. T. Murray, rev. W. F. Wyatt, Harvard University Press, Cambridge MA, 1999.

Pausanias, Description of Greece, 5 vols, transl. W. H. S. Jones, Harvard University Press, Cambridge MA, 1918-35.

Philochoros, in F. Jacoby (ed.), Die Fragmente der griechischen Historiker, Weidmann, Berlin, 1923-.

Photios, in J. H. Freese, The Library of Photius, Macmillan, New York, 1920-.

Scholia in Aratum vetera, ed. J. Martin, Teubner, Stuttgart, 1974.

\section{Modern sources:}

Burkert, W. 1983, Homo Necans. The Anthropology of Ancient Greek Sacrificial Ritual and Myth, University of California Press, Berkeley.

Davidson, J. 2007, Time and Greek religion. In D. Ogden (ed.), A Companion to Greek Religion, Blackwell, Oxford, pp. 204-218.

Hurwit, J. M. 1999, The Athenian Acropolis. History, Mythology and Archaeology from the Neolithic Era to the Present, Cambridge University Press, Cambridge. 